\title{
Determinants of Knowledge and Practice of Infection Prevention and Control among Healthcare Workers during COVID-19 Outbreak in Nigeria
}

\author{
Ipinnimo Tope Michael ${ }^{1 *}$, Sanni Taofeek Adedayo ${ }^{1}$, Ariyo Olumuyiwa Elijah ${ }^{2}$, Ipinnimo \\ Oluwadare Martin ${ }^{3}$ \\ ${ }^{1}$ Department of Community Medicine, Federal Teaching Hospital, Ido-Ekiti, Ekiti State, \\ Nigeria \\ ${ }^{2}$ Department of Medicine, Federal Teaching Hospital, Ido-Ekiti, Ekiti State, Nigeri \\ ${ }^{3}$ Department of Obstetrics and Gynaecology, Ekiti State University Teaching Hospital, Ado- \\ Ekiti, Ekiti State, Nigeria \\ *Corresponding Author: abbeymagnus@yahoo.com
}

\begin{abstract}
Aim: This study aimed to identify factors affecting knowledge and practice of infection prevention and control (IPC) among healthcare workers (HCW) during COVID-19 outbreak in Nigeria.

Method: An online sample of 402 Nigerian HCW was recruited in April, 2020 via their social media closed user group chats. Data was collected online using questionnaire that was adapted from the study by Melaku et al. Data analysis was done with computer software IBM SPSS version 20.0.

Results: Three hundred and thirty-one (82.3\%) had good knowledge of IPC while only 230 (57.2\%) had good practice of IPC. Age group $(p<0.001)$, profession $(p=0.005)$, type of health facility $(p=0.014)$ and IPC training $(p<0.001)$ were significantly associated with the knowledge of IPC while sex ( $p=0.005)$, profession ( $p=0.009)$, type of health facility $(p<0.001)$, IPC training $(p<0.001)$ and availability of water in health facility $(p=0.014)$ were significantly associated with the practice among the HCW. After multiple logistic regression analysis, age group, type of health facility and IPC training remain significant predictors of knowledge while sex, type of health facility, IPC training and availability of water in the health facility remain significant predictors of practice of IPC among $\mathrm{HCW}$.

Conclusion: Secondary to these findings, regular IPC training of HCW and making sure water is always available at health facilities was suggested. This study also recommends that special considerations should be given to males, older and primary health facilities $\mathrm{HCW}$ in order to improve their knowledge and practice of IPC which is important in limiting infections among them.
\end{abstract}

Keywords: Infection Prevention and Control; COVID_19; Healthcare Workers; Nigeria.

\section{Introduction}

The coronavirus disease 2019 (COVID-19) was first reported late in December, 2019 in Wuhan City, Hubei province of China. ${ }^{1}$ It has since then spread to other provinces of China and countries of the world. The first case outside China was detected in Thailand, another country in Asia while in Africa; Egypt was the first country to report a case. ${ }^{2}$ Nigeria reported her first case in February 27, 2020 in a man who just returned from Italy, making Nigeria the third country to report a case in Africa. ${ }^{2,3}$ The WHO declared the COVID-19 a Public Health Emergency of International Concern (PHEIC) in
January $31^{4}$ and by March 11, 2020 the disease was characterized as a pandemic. ${ }^{5}$

COVID-19 first death was reported in China during the second week of January, 2020. The first mortality in Nigeria was recorded two months after, from a 67years old man who just returned from United Kingdom. ${ }^{6}$ As at April 17, 2020 , there are 135,163 deaths from 2,034,802 confirmed cases affecting 213 countries, areas or territories. $^{7}$ The Nigeria Centre for Disease control reported 442 confirmed cases in the country with a case fatality rate of $2.9 \%$ during the same period. ${ }^{6}$ Healthcare workers (HCW) are not spared from the impact of the disease. They are infected both in the community just 
like every other person and as hospital acquired infection at their place of work. In order to reduce human to human transmission, most countries are on lockdown asking citizens to stay at home and maintain social distancing, however HCW continue to go about their routines putting them at higher risk of getting infected.

There were already over $3,000 \mathrm{HCW}$ infections as at late February to early March, 2020 and 22 had died. ${ }^{8,9}$ In Italy, $20 \%$ of responding $\mathrm{HCW}$ were infected constituting about $9 \%$ of all cases. ${ }^{9,10}$ Healthcare workers infection rate is on the rise with Spain recording a higher rate in late March, 2020 of over 12\% according to the Spanish government official. In Nigeria, according to local media, HCW infection and mortality have also been reported as at the time of this report. The psychological and mental health impact of the current pandemic can equally increase the risk of infection. ${ }^{9}$ It is said that $\mathrm{HCW}$ at risk of contact with COVID-19 patients were the most common risk factors for insomnia, anxiety, obsessivecompulsive symptoms, and depression. ${ }^{11}$

The fact that $\mathrm{HCW}$ are affected by this virus is a serious issue because of the major role they play in controlling the disease; they could also serve as reservoir of infection for patients seeking care for other illnesses. It is therefore important to protect the health workforce and limit infection among them. Infection among HCW results from lack of good practices of infection prevention and control (IPC) measures. ${ }^{12}$ Good practice of IPC is driven by good attitude and knowledge. ${ }^{13}$ Healthcare workers knowledge and adherence toward general IPC strategies is still very low. ${ }^{13,14}$ Some of the factors that contribute to good knowledge and practice of IPC include; older age, years of work experience, ${ }^{15}$ higher educational status, training, and availability of infection prevention supplies. ${ }^{14}$

Infection prevention and control of SARS CoV-2 and COVID-19 is a new area of interest with only little available information and research. This study will compliment available literatures and serve as basis for other studies; it would also influence training and policies that deal with protecting the human resource for health against COVID-19 and other infectious diseases. The aim of this study is to identify factors affecting knowledge and practice of IPC among HCW during COVID-19 outbreak in Nigeria.

\section{Materials and methods}

This was a quantitative descriptive crosssectional study conducted in late April, 2020. The study was performed through an online survey using Google forms due to lock down and the need for social distancing during the period of COVID-19 pandemic. The study population included all $\mathrm{HCW}$ in Nigeria practicing during the period of the study.

A sample size of 384 was calculated using single population proportion formula, $n=Z^{2} p(1$ $\mathrm{p}) / \mathrm{d}^{2}$. The prevalence of good practice of IPC during COVID-19 pandemic was assumed to be $50 \%$ (since there was no previous study in Nigeria). 95\% confidence interval and 5\% of marginal error were used. An adjustment for $10 \%$ inappropriate entries gave a sample size of 422. The google forms was sent to social media closed user group chats of HCW in Nigeria and was pulled out when the number of filled forms got to the required sample size.

Data was collected online using a questionnaire that was adapted from the study by Melaku et al. ${ }^{14}$ The questionnaire consists of three sections. Section A elicited the sociodemographic variables of the respondents such as age, gender, marital status, highest level of education Et cetera. Section B assessed respondent's knowledge of IPC during the COVID-19 outbreak. The last part, Section C assessed respondent's practice of IPC during the COVID-19 outbreak. There are 8 questions each in Section $\mathrm{B}$ and $\mathrm{C}$ assessing knowledge and practice of IPC. These questions were answered with a Yes/No option. A correct answer was assigned 1 point and incorrect assigned 0 point making the least obtainable score to be 0 and highest obtainable score to be 8 . A cumulative mean cut off of 4 was set. Respondent who have scored above the cumulative mean cut off was said to have good knowledge or good practice and those who score below were said to have poor knowledge or poor practice.

The instrument was reviewed by experts in Infectious Disease Unit of Federal Teaching Hospital, Ido-Ekiti for face and content validity. The questionnaire was tested for internal consistency using test-retest reliability test and Cronbach's Alpha score was 0.74 . 
Data analysis was conducted using computer software IBM SPSS version 20.0 Descriptive statistics was presented using frequency tables. Continuous variables such as age were summarized as mean and standard deviation while categorical variables were summarized as frequency and percentages. Pearson chi-square was use to compare two variables. Binary logistic regression was used to identify the predictors of knowledge and practice of IPC. Level of significance was set at 5\%.

The Human Ethics and Research Committee of Federal Teaching Hospital, Ido-Ekiti gave approval for this study. Consent would be taken from participant by ticking a yes/no question to determine their willingness to voluntarily partake in the study. Confidentiality and anonymity were maintained.

\section{Results}

A total of $402 \mathrm{HCW}$ completed the survey questionnaire appropriately. Table 1 shows the socio-demographic characteristics of the HCW. The mean ( \pm Standard deviation) age was 35.0 $( \pm 10.6)$ years. More than two-third of the HCW were females $(69.7 \%$; $n=280), 227(56.5 \%)$ were married and majority had at least tertiary level of education $(96.8 \% ; n=389)$. About half of the HCW were nurses $(49.5 \%$; $n=199)$ and about another half practiced in government tertiary health facility $(51.3 \% ; \mathrm{n}=206)$. The median ( \pm Interquartile range) year of practice was 6.0 $( \pm 8.0)$. About one-third of the HCW never had IPC training (30.6\%; $n=123)$. Majority of them had water available in their health facility (96.5\%; $\mathrm{n}=388)$ with over two-third of the water supplied from tap (78.3\%; $\mathrm{n}=304)$. When asked about availability of IPC supplies, 155 (38.6\%) said it was lacking.

Figures 1 and 2 summarized the knowledge and practice of IPC among the HCW respectively. Three hundred and thirty-one $(82.3 \%)$ had good knowledge of IPC while only $230(57.2 \%)$ had good practice of IPC. There were $71(17.7 \%)$ and $172(42.8 \%)$ of them with poor knowledge and practice of IPC respectively.

At the bivariate level of analysis, table 2 shows that four factors were significantly associated with knowledge of IPC. They include: Age group $(\mathrm{p}<0.001)$, profession $(\mathrm{p}=0.005)$, type of health facility $(\mathrm{p}=0.014)$ and IPC training $(\mathrm{p}<0.001)$. Sex, marital status, level of education, years of practice, availability of water in the health facility, source of water and availability of IPC supplies were not significantly associated with the knowledge of IPC ( $p>0.05)$.

The factors that were significantly associated with practice of IPC were shown in table 3. These factors include: Sex ( $\mathrm{p}=0.005)$, profession $(\mathrm{p}=0.009)$, type of health facility $(\mathrm{p}<0.001)$, IPC training $(\mathrm{p}<0.001)$ and availability of water in health facility $(\mathrm{p}=0.014)$. Source of water, age group, marital status, level of education, years of practice, availability of IPC supplies and knowledge of IPC were not significantly associated with the practice among the HCW ( $>0.05)$.

Table 4 shows the result of multivariate logistic regression analysis indicating the predictors of knowledge of IPC. At this level of analysis, age group, type of health facility and IPC training were the only significant predictors of knowledge. In respect to age, as the age of $\mathrm{HCW}$ increases the knowledge of IPC reduces. $\mathrm{HCW}$ who are in the age groups 31 to 40 years, 41 to 50 years and 51 years and above were about $71 \%, 81 \%$ and $89 \%$ respectively less likely to have good knowledge of IPC than those aged 30 years and below $(31-40$ years: $\mathrm{OR}=$ $0.288,95 \% \mathrm{CI}=[0.132-0.626] ; 41-50$ years: $\mathrm{OR}=0.188,95 \% \mathrm{CI}=[0.074-0.475] ; \geq 51$ years: $\mathrm{OR}=0.107,95 \% \mathrm{CI}=[0.038-0.302])$. In regard to type of health facility, HCW working in government tertiary health were about 3 times more likely to have good knowledge of IPC than those working in primary health facilities $(\mathrm{OR}=2.729,95 \% \mathrm{CI}=$ [1.212 - 6.143]). Also, HCW who ever had training of IPC had better knowledge than those who never did. Those who ever had training but not in the last 3 months were 3 times more likely to have good knowledge of IPC than those who never had $(\mathrm{OR}=3.194,95 \% \mathrm{CI}=[1.258-$ 8.108]). Those who had training in the last 3 months were about 4 times more likely to have good knowledge than those who never had (OR $=3.868,95 \% \mathrm{CI}=[1.952-7.667])$.

The predictors of good practice of IPC are shown in Table 5. Sex, type of health facility, IPC training and availability of water in the health facility were the significant predictors of practice. Female HCW are about 2 times more likely to engage in good practice of IPC than male $\mathrm{HCW}(\mathrm{OR}=2.361,95 \% \mathrm{CI}=[1.417-$ 
3.933]). Private health facilities HCW are $63 \%$ less likely to engage in good practice of IPC than those in government primary health facilities $(\mathrm{OR}=0.374,95 \% \mathrm{CI}=[0.164-$ 0.851]). HCW with available water in their health facility were 14 times more likely to engage in good practice of IPC than those with no available water in their health facility. (OR = 14.009, 95\% CI $=[3.078$ - 63.747]). Lastly, HCW who ever had training but not in the last 3 months and those who had training in the last 3 months were 3 and 4 times respectively more likely to engage in good practice of IPC than those who never had (Ever had but not in the last 3 month: $\mathrm{OR}=2.928,95 \% \mathrm{CI}=[1.723-$ 4.976]; In the last 3 month: $\mathrm{OR}=4.204,95 \% \mathrm{CI}$ $=[2.079-8.503])$.

\section{Discussion}

Hospital infection prevention and control (IPC) is very crucial to limit infection spread among HCW. This is hinge on the knowledge and practice of IPC among the workforce. The importance of this cannot be overemphasized during the pandemic of COVID-19 with no preventive vaccines and approved treatment modality $^{8-9,12}$ This study assessed the determinants of knowledge and practice of IPC among HCW during COVID-19 pandemic in Nigeria. The demography showed that the mean age of HCW in this study was $35 \pm 10$.6years. This finding is similar to findings in a study on infection control practice among various occupational groups in Vietnam where mean of $35.8 \pm 11.1$ years was reported and in another study done on infection control among nurses in selected hospitals in Anambra State, Nigeria where mean age of $37.4 \pm 10.7$ yerars was documented. ${ }^{13,16}$ However, it is slightly higher than the mean age of $27.75 \pm 4$.18years documented in a study in Bir Hospital, Khatmandu. ${ }^{17}$ This implies that the health workforce in Nigeria is constituted majorly of young population, just like the country's demography ${ }^{18}$ which must be well protected.

More than two third of the respondents in this study are females, accounting for $69.7 \%$ of HCW. This may be because about half of this study respondents were nurses. Nurses make up a high proportion of healthcare workforce of the country and are majorly females. The higher proportion of female to male as seen in this study is similar to that as reported in Vietnam where majority of hospital respondents were females in both urban and rural hospital surveyed $(89.9 \%$ and $81.8 \%$ respectively with an average of $86.5 \%){ }^{13}$ This finding is however contrast to the report documented among HCW in Debre Markos referral hospital, Northwest Ethiopia where it was found that a higher percentage of respondents (62\%) were males. ${ }^{14}$

The average year of practice in this study was 6.0 years. This finding is close to the median year of experience 7years (IQR 4-12) reported in a study done to determine knowledge and practice of infection control among healthcare workers in Northwest Nigeria. ${ }^{12}$

Majority $(96.5 \%)$ of the healthcare facilities in this study have water supply but a large number had poor supply of other IPC materials for IPC practices. This is similar to the findings in Anambra State, Nigeria where about $80.7 \%$ of the health facilities have available running water. ${ }^{16}$ the poor supply of IPC materials has great implications for COVID-19 HCW infections prevention making many vulnerable and demotivated in tackling the outbreak. This will further worsen the poor healthcare system in the country, therefore, inadequate supply of IPC materials needed to be given necessary attention that it deserves.

More than four-fifth $(82.3 \%)$ of HCW in this study have good knowledge of IPC. This could be due to increase in awareness and sensitization on IPC during the pandemic period. This result is similar to findings among $\mathrm{HCW}$ in Debre Markos Northwest Ethiopia, and Northwest Nigeria where good knowledge of $84.6 \%$ and $70 \%$ respectively were reported. ${ }^{12,14}$ However, it is higher than the rate reported in studies done in Vietnam and Nepal among HCW where a lower rate of $65.3 \%$ and $57.1 \%$ was documented respectively. ${ }^{13,17}$

A little above half $(57.2 \%)$ of the respondents engage in good practice of IPC despite the fear of COVID-19 infection. It may also be expected that this number would be higher considering the high knowledge rate. However, no significant association was found between knowledge and practice of IPC in this study. The practice rate is similar to practice of IPC in studies done among $\mathrm{HCW}$ in and outside Nigeria where $50.7 \%, 57.3 \%$ and $65 \%$ practice rate was reported. ${ }^{12,13,14}$ Less than half $(48.2 \%)$ of HCW in Nepal engage in good practice of IPC and this is lower than the finding in this 
study. ${ }^{17}$ The observation in this study and similar studies clearly shows that good IPC knowledge is higher than good IPC practice. The understanding of the determinants of both could help in specific interventions to improve on IPC among HCW and reduce COVID_19 and other hospital-acquired infections.

Factors associated with knowledge of IPC from this study include age, profession, types of health facility and previous training on IPC. Healthcare workers 30years and below tends to have better knowledge than their older counterparts. The reason for this may be because the younger $\mathrm{HCW}$ are still fresh from school and can still remember IPC that were taught in their school curriculum; also, they are exposed to newer IPC training from school while the older ones might find it difficult to remember the things that were taught in school. However, this finding was in contrast to the findings in the study done in Ethiopia where older age was reported to have good association with knowledge and practice of IPC. ${ }^{12}$ Healthcare workers in government tertiary health facilities have better knowledge than those in primary health facilities. Tertiary health facilities are training institutions and $\mathrm{HCW}$ in them are exposed to continuous training programme. This is consistent with the factors (IPC training, cadre, and station of practice) documented in studies conducted among HCW in Nigeria and abroad. $^{12,14}$

Factors associated with good practice are sex (female gender), profession, and type of health facility (private health facility), IPC training (in the last 3months) and availability of water in health facilities. These factors are similar to the factors (gender, cadre and station of practice) documented in study by Iliyasu et al. ${ }^{12}$ This study found that HCW with available water in their health facility were 14 times more likely to engage in good practice of IPC than those with no available water in their health facility. This is because water is a very important element for hand hygiene. It is a universal solvent that is used for cleaning surfaces and materials. Water is also used to dilute disinfectant such as hypochloride solutions before use. This agent seems central and indispensable to IPC in the health facilities. Its availability is therefore important and non-negotiable for good IPC practices in any health facilities.

One of the limitations of this study is the assessment of practice of IPC using a selfreported method. This could also be affected by recall bias, as the recall abilities of respondents differ. A direct observation of practice of IPC by HCW would have been more appropriate. This study used only quantitative method; introduction of a qualitative research method would have helped to enrich it content.

\section{Conclusion}

A thorough understanding of the determinants of knowledge and practice of IPC among HCW provide the opportunity for appropriate intervention toward taming the COVID-19 monster and by extension other infectious diseases outbreak in and outside of outbreak in the day-to-day affairs of health institutions. This could help to reverse the incidence of nosocomial infections and reduce it associated morbidity and mortality. This study found a high rate of good knowledge of IPC but this did not translate into high rate of good practice of IPC among HCW. Advancing age, working in government primary health facility and lack of training on IPC were identified as predictors of poor knowledge while male gender, working in government primary health facility, lack of training on IPC and non-availability of water in health facility were found to predict poor practice of IPC among HCW.

This study therefore recommends that it is important to create new policies or support existing ones that would bring about regular IPC training of all HCW in Nigeria. Also, institutions and health facilities should ensure availability of running water at every clinic, wards and other care areas for hand hygiene which will improve the practice of IPC. Special consideration must be placed on high risk HCW such as male workers, older workers and those working in primary health facilities so that they can be protected against COVID-19 and other nosocomial infections. 


\section{Figures and Tables}

Table 1. Socio-Demographic Characteristics of Respondents

\begin{tabular}{|c|c|c|}
\hline Variable & Frequency $(\mathrm{N}=402)$ & Percentage (\%) \\
\hline \multicolumn{3}{|l|}{ Age Group (Years) } \\
\hline$\leq 30$ years & 175 & 43.5 \\
\hline $31-40$ years & 132 & 32.8 \\
\hline $41-50$ years & 62 & 15.5 \\
\hline$\geq 51$ years & 33 & 8.2 \\
\hline Mean Age $\pm S D$ & $35.0 \pm 10.6$ & \\
\hline \multicolumn{3}{|l|}{ Sex } \\
\hline Male & 122 & 30.3 \\
\hline Female & 280 & 69.7 \\
\hline \multicolumn{3}{|l|}{ Marital Status } \\
\hline Unmarried & 175 & 43.5 \\
\hline Married & 227 & 56.5 \\
\hline \multicolumn{3}{|l|}{ Level of Education } \\
\hline Pre-tertiary & 13 & 3.2 \\
\hline Tertiary & 261 & 64.9 \\
\hline Postgraduate & 128 & 31.9 \\
\hline \multicolumn{3}{|l|}{ Profession } \\
\hline Medical Doctor & 109 & 27.1 \\
\hline Nurse & 199 & 49.5 \\
\hline Others (e.g CHEW) & 94 & 23.4 \\
\hline \multicolumn{3}{|l|}{ Years of Practice } \\
\hline $1-6$ years & 226 & 56.2 \\
\hline$>6$ years & 176 & 43.8 \\
\hline Median $\pm I Q R$ & $6.0 \pm 8.0$ & \\
\hline \multicolumn{3}{|l|}{ Type of Health Facility } \\
\hline $\begin{array}{l}\text { Government Primary } \\
\text { Health Facilities (PHF) }\end{array}$ & 50 & 12.4 \\
\hline $\begin{array}{l}\text { Government Secondary } \\
\text { Health Facilities (SHF) }\end{array}$ & 60 & 14.9 \\
\hline $\begin{array}{l}\text { Government Tertiary } \\
\text { Health Facilities (THF) }\end{array}$ & 206 & 51.3 \\
\hline Private Health Facilities & 86 & 21.4 \\
\hline \multicolumn{3}{|l|}{ Had any IPC Training } \\
\hline Never before & 123 & 30.6 \\
\hline $\begin{array}{l}\text { Ever before but not in last } \\
3 \text { months }\end{array}$ & 204 & 50.7 \\
\hline In the last 3 months & 75 & 18.7 \\
\hline \multicolumn{3}{|c|}{ Availability of Water in the Health Facility } \\
\hline No & 14 & 3.5 \\
\hline Yes & 388 & 96.5 \\
\hline \multicolumn{3}{|c|}{ If Yes, What the source? $(\mathrm{n}=\mathbf{3 8 8})$} \\
\hline Tap & 304 & 78.3 \\
\hline Veronica bucket & 46 & 11.9 \\
\hline $\begin{array}{l}\text { Others (e.g bucket and } \\
\text { bowl) }\end{array}$ & 38 & 9.8 \\
\hline \multicolumn{3}{|c|}{ Availability of IPC Supplies } \\
\hline No & 155 & 38.6 \\
\hline Yes & 247 & 61.4 \\
\hline
\end{tabular}




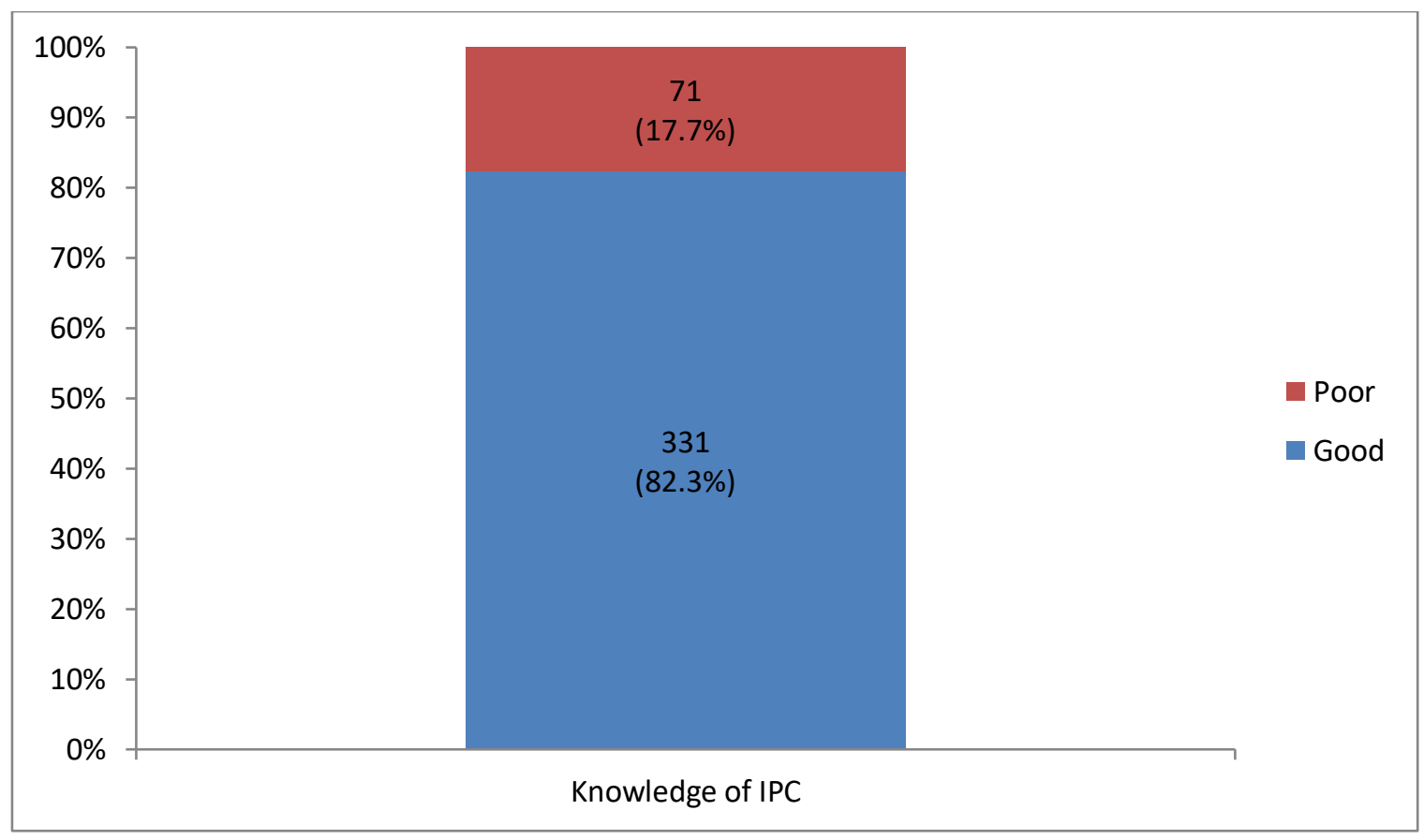

Figure 1. Level of Knowledge of IPC among Respondents

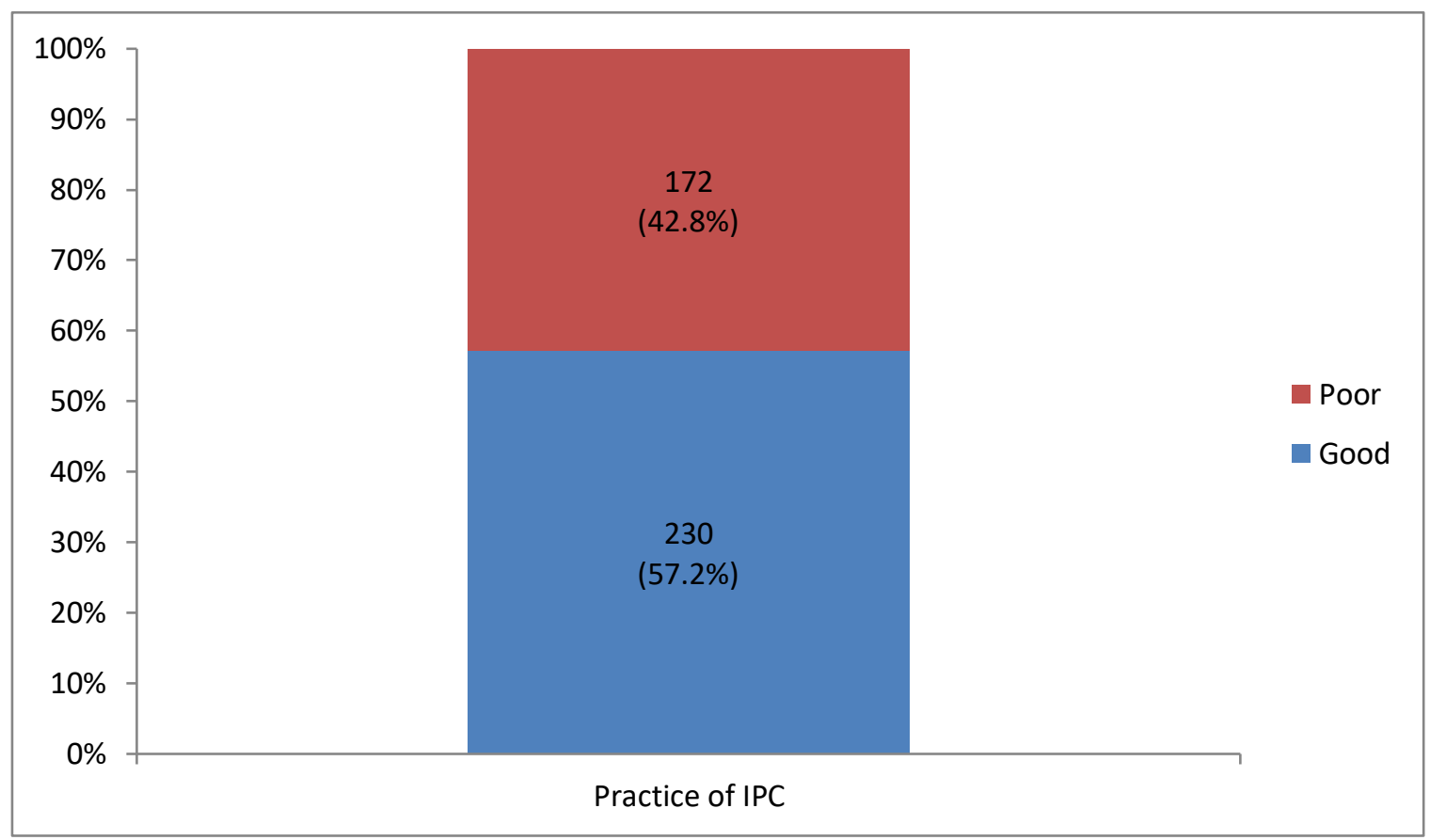

Figure 2. Prevalence of good practice of IPC among Respondents 
Table 2. Comparison of Respondents' factors with Knowledge of IPC

\begin{tabular}{|c|c|c|c|c|c|}
\hline \multirow{2}{*}{ Variable } & \multicolumn{3}{|c|}{ Knowledge of IPC } & \multirow{2}{*}{$\mathbf{X} 2$} & \multirow[t]{2}{*}{ p-value } \\
\hline & $\begin{array}{c}\text { Good n } \\
(\%)\end{array}$ & $\begin{array}{c}\text { Poor n } \\
(\%)\end{array}$ & $\begin{array}{c}\text { Total n } \\
(\%)\end{array}$ & & \\
\hline \multicolumn{6}{|l|}{ Age Group (Years) } \\
\hline$\leq 30$ years & $159(90.9)$ & $16(9.1)$ & 175 & 20.194 & $<0.001$ \\
\hline $31-40$ years & $106(80.3)$ & $26(19.7)$ & 132 & & \\
\hline 41-50 years & $44(71.0)$ & $18(29.0)$ & 62 & & \\
\hline$\geq 51$ years & $22(66.7)$ & $11(33.3)$ & 33 & & \\
\hline \multicolumn{6}{|l|}{ Sex } \\
\hline Male & $103(84.4)$ & $19(15.6)$ & 122 & 0.525 & 0.469 \\
\hline Female & $228(81.4)$ & $52(18.6)$ & 280 & & \\
\hline \multicolumn{6}{|l|}{ Marital Status } \\
\hline Unmarried & $148(84.6)$ & $27(15.4)$ & 175 & 1.063 & 0.303 \\
\hline Married & $183(80.6)$ & $44(19.4)$ & 227 & & \\
\hline \multicolumn{6}{|l|}{ Level of Education } \\
\hline Pre-tertiary & $10(76.9)$ & $3(23.1)$ & 13 & $1.369^{\mathrm{F}}$ & 0.496 \\
\hline Tertiary & $212(81.2)$ & $49(18.8)$ & 261 & & \\
\hline Postgraduate & $109(85.2)$ & $19(14.8)$ & 128 & & \\
\hline \multicolumn{6}{|l|}{ Profession } \\
\hline Medical Doctor & $92(84.4)$ & $17(15.6)$ & 109 & 10.522 & 0.005 \\
\hline Nurse & $172(86.4)$ & $27(13.6)$ & 199 & & \\
\hline Others (e.g CHEW) & $67(71.3)$ & $27(28.7)$ & 94 & & \\
\hline \multicolumn{6}{|l|}{ Years of Practice } \\
\hline $1-6$ years & $189(83.6)$ & $37(16.4)$ & 226 & 0.591 & 0.442 \\
\hline$>6$ years & $142(80.7)$ & $34(19.3)$ & 176 & & \\
\hline \multicolumn{6}{|l|}{ Type of Health Facility } \\
\hline Government PHF & $35(70.0)$ & $15(30.0)$ & 50 & 10.627 & 0.014 \\
\hline Government SHF & $55(91.7)$ & $5(8.3)$ & 60 & & \\
\hline Government THF & $174(84.5)$ & $32(15.5)$ & 206 & & \\
\hline Private Health Facilities & $67(77.9)$ & $19(22.1)$ & 86 & & \\
\hline \multicolumn{6}{|l|}{ Had any IPC Training } \\
\hline Never before & $87(70.7)$ & $36(29.3)$ & 123 & 17.145 & $<0.001$ \\
\hline $\begin{array}{l}\text { Ever before but not in last } 3 \\
\text { months }\end{array}$ & $176(86.3)$ & $28(13.7)$ & 204 & & \\
\hline In the last 3 months & $68(90.7)$ & $7(9.3)$ & 75 & & \\
\hline \multicolumn{6}{|c|}{ Availability of Water in the Health Facility } \\
\hline No & $11(78.6)$ & $3(21.4)$ & 14 & $<0.001^{\mathrm{Y}}$ & 0.984 \\
\hline Yes & $320(82.5)$ & $68(17.5)$ & 388 & & \\
\hline \multicolumn{6}{|c|}{ If Yes, What the source? $(n=388)$} \\
\hline Tap & $246(80.9)$ & $58(19.1)$ & 304 & 0.576 & 0.750 \\
\hline Veronica bucket & $39(84.8)$ & $7(15.2)$ & 46 & & \\
\hline Others (e.g bucket and bowl) & $32(84.2)$ & $6(15.8)$ & 38 & & \\
\hline \multicolumn{6}{|l|}{ Availability of IPC Supplies } \\
\hline No & $126(81.3)$ & $29(18.7)$ & 155 & 0.191 & 0.662 \\
\hline Yes & $205(83.0)$ & $42(17.0)$ & 247 & & \\
\hline
\end{tabular}

$\mathrm{X}^{2}$ : Pearson Chi Square; ${ }^{\mathrm{Y}}$ : Continuity Correction; ${ }^{\mathrm{F}}$ : Fisher's Exact Test 
Table 3. Comparison of Respondents' factors with Practice of IPC

\begin{tabular}{|c|c|c|c|c|c|}
\hline \multirow[b]{2}{*}{ Variable } & \multicolumn{3}{|c|}{ Practice of IPC } & \multirow[b]{2}{*}{$\mathbf{X}^{2}$} & \multirow[b]{2}{*}{ p-value } \\
\hline & Good n (\%) & $\begin{array}{c}\text { Poor } \mathrm{n} \\
(\%)\end{array}$ & $\begin{array}{c}\text { Total N } \\
(\%)\end{array}$ & & \\
\hline \multicolumn{6}{|l|}{ Age Group (Years) } \\
\hline$\leq 30$ years & $93(53.1)$ & $82(46.9)$ & 175 & 5.983 & 0.112 \\
\hline $31-40$ years & $75(56.8)$ & $57(43.2)$ & 132 & & \\
\hline $41-50$ years & $37(59.7)$ & $25(40.3)$ & 62 & & \\
\hline$\geq 51$ years & $25(75.8)$ & $8(24.2)$ & 33 & & \\
\hline \multicolumn{6}{|l|}{ Sex } \\
\hline Male & $57(46.7)$ & $65(53.3)$ & 122 & 7.878 & 0.005 \\
\hline Female & $173(61.8)$ & $107(38.2)$ & 280 & & \\
\hline \multicolumn{6}{|l|}{ Marital Status } \\
\hline Unmarried & $94(53.7)$ & $81(46.3)$ & 175 & 1.551 & 0.213 \\
\hline Married & $136(59.9)$ & $91(40.1)$ & 227 & & \\
\hline \multicolumn{6}{|l|}{ Level of Education } \\
\hline Pre-tertiary & $7(53.8)$ & $6(46.2)$ & 13 & 1.078 & 0.583 \\
\hline Tertiary & $145(55.6)$ & $116(44.4)$ & 261 & & \\
\hline Postgraduate & $78(60.9)$ & $50(39.1)$ & 128 & & \\
\hline \multicolumn{6}{|l|}{ Profession } \\
\hline Medical Doctor & $65(59.6)$ & $44(40.4)$ & 109 & 9.472 & 0.009 \\
\hline Nurse & $124(62.3)$ & $75(37.7)$ & 199 & & \\
\hline Others (e.g CHEW) & $41(43.6)$ & $53(56.4)$ & 94 & & \\
\hline \multicolumn{6}{|l|}{ Years of Practice } \\
\hline $1-6$ years & $127(56.2)$ & $99(43.8)$ & 226 & 0.219 & 0.640 \\
\hline$>6$ years & $103(58.5)$ & $73(41.5)$ & 176 & & \\
\hline \multicolumn{6}{|l|}{ Type of Health Facility } \\
\hline Government PHF & $23(46.0)$ & $27(54.0)$ & 50 & 21.324 & $<0.001$ \\
\hline Government SHF & $31(51.7)$ & $29(48.3)$ & 60 & & \\
\hline Government THF & $140(68.0)$ & $66(32.0)$ & 206 & & \\
\hline Private Health Facilities & $36(41.9)$ & $50(58.1)$ & 86 & & \\
\hline \multicolumn{6}{|l|}{ Had any IPC Training } \\
\hline Never before & $50(40.7)$ & $73(59.3)$ & 123 & 19.890 & $<0.001$ \\
\hline Ever before but not in last 3 months & $131(64.2)$ & $73(35.8)$ & 204 & & \\
\hline In the last 3 months & $49(65.3)$ & $26(34.7)$ & 75 & & \\
\hline \multicolumn{6}{|c|}{ Availability of Water in the Health Facility } \\
\hline No & $3(21.4)$ & $11(78.6)$ & 14 & $6.149^{\mathrm{Y}}$ & 0.013 \\
\hline Yes & $227(58.5)$ & $161(41.5)$ & 388 & & \\
\hline \multicolumn{6}{|l|}{ If Yes, What the source? $(n=388)$} \\
\hline Tap & $184(60.5)$ & $120(39.5)$ & 304 & 2.837 & 0.242 \\
\hline Veronica bucket & $22(47.8)$ & $24(52.2)$ & 46 & & \\
\hline Others (e.g bucket and bowl) & $21(55.3)$ & $17(44.7)$ & 38 & & \\
\hline \multicolumn{6}{|l|}{ Availability of IPC Supplies } \\
\hline No & $84(54.2)$ & $71(45.8)$ & 155 & 0.940 & 0.332 \\
\hline Yes & $146(59.1)$ & $101(40.9)$ & 247 & & \\
\hline \multicolumn{6}{|l|}{ Knowledge of IPC } \\
\hline Good & $183(55.3)$ & $148(44.7)$ & 331 & 2.843 & 0.092 \\
\hline Poor & $47(66.2)$ & $24(33.8)$ & 71 & & \\
\hline
\end{tabular}

$\mathrm{X}^{2}$ : Pearson Chi Square; ${ }^{\text {Y: }}$ Continuity Correction; ${ }^{\mathrm{F}}$ : Fisher's Exact Test 
Table 4. Predictors of Good Knowledge of IPC

\begin{tabular}{|c|c|c|c|c|c|}
\hline \multirow[b]{2}{*}{ Variable } & \multirow[b]{2}{*}{ B } & \multirow[b]{2}{*}{ p-value } & \multirow[b]{2}{*}{$\begin{array}{l}\text { Odd } \\
\text { Ratio }\end{array}$} & \multicolumn{2}{|c|}{ 95\% Confidence Interval } \\
\hline & & & & Lower & Upper \\
\hline \multicolumn{6}{|l|}{ Age Group (Years) } \\
\hline \multicolumn{6}{|l|}{$\leq 30$ years $($ Ref $)$} \\
\hline $31-40$ years & -1.246 & 0.002 & 0.288 & 0.132 & 0.626 \\
\hline $41-50$ years & -1.674 & $<0.001$ & 0.188 & 0.074 & 0.475 \\
\hline$\geq 51$ years & -2.233 & $<0.001$ & 0.107 & 0.038 & 0.302 \\
\hline \multicolumn{6}{|l|}{ Profession } \\
\hline \multicolumn{6}{|l|}{$\begin{array}{l}\text { Medical Doctor } \\
\text { (Ref) }\end{array}$} \\
\hline Nurse & 0.129 & 0.750 & 1.137 & 0.516 & 2.505 \\
\hline Others (e.g CHEW) & -0.045 & 0.914 & 0.956 & 0.423 & 2.161 \\
\hline \multicolumn{6}{|c|}{ Type of Health Facility } \\
\hline \multicolumn{6}{|c|}{\begin{tabular}{l|l} 
Government PHF & \\
(Ref)
\end{tabular}} \\
\hline Government SHF & 1.012 & 0.097 & 2.752 & 0.834 & 9.085 \\
\hline Government THF & 1.004 & 0.015 & 2.729 & 1.212 & 6.143 \\
\hline $\begin{array}{l}\text { Private Health } \\
\text { Facilities }\end{array}$ & -0.161 & 0.730 & 0.851 & 0.340 & 2.131 \\
\hline \multicolumn{6}{|c|}{ Had any IPC Training } \\
\hline \multicolumn{6}{|c|}{ Never before (Ref) } \\
\hline $\begin{array}{l}\text { Ever before but not } \\
\text { in last } 3 \text { months }\end{array}$ & 1.161 & 0.015 & 3.194 & 1.258 & 8.108 \\
\hline In the last 3 months & 1.353 & $<0.001$ & 3.868 & 1.952 & 7.667 \\
\hline
\end{tabular}

Table 5. Predictors of Good Practice of IPC

\begin{tabular}{|c|c|c|c|c|c|}
\hline \multirow{2}{*}{ Variable } & \multirow{2}{*}{ B } & \multirow{2}{*}{ p-value } & \multirow{2}{*}{ Odd Ratio } & \multicolumn{2}{|c|}{ 95\% Confidence Interval } \\
\hline & & & & Lower & Upper \\
\hline \multicolumn{6}{|l|}{ Sex } \\
\hline \multicolumn{6}{|l|}{ Male (Ref) } \\
\hline Female & 0.859 & 0.001 & 2.361 & 1.417 & 3.933 \\
\hline \multicolumn{6}{|l|}{ Profession } \\
\hline \multicolumn{6}{|l|}{ Medical Doctor (Ref) } \\
\hline Nurse & -0.025 & 0.930 & 0.975 & 0.560 & 1.700 \\
\hline Others (e.g CHEW) & -0.589 & 0.066 & 0.555 & 0.297 & 1.039 \\
\hline \multicolumn{6}{|l|}{ Type of Health Facility } \\
\hline \multicolumn{6}{|l|}{ Government PHF (Ref) } \\
\hline Government SHF & -0.575 & 0.202 & 0.563 & 0.233 & 1.360 \\
\hline Government THF & 0.642 & 0.080 & 1.901 & 0.927 & 3.900 \\
\hline Private Health Facilities & 0.984 & 0.019 & 0.374 & 0.164 & 0.851 \\
\hline \multicolumn{6}{|l|}{ Had any IPC Training } \\
\hline \multicolumn{6}{|l|}{ Never before (Ref) } \\
\hline $\begin{array}{l}\text { Ever before but not in last } 3 \\
\text { months }\end{array}$ & 1.074 & $<0.001$ & 2.928 & 1.723 & 4.976 \\
\hline In the last 3 months & 1.436 & $<0.001$ & 4.204 & 2.079 & 8.503 \\
\hline \multicolumn{6}{|c|}{ Availability of Water in the Health Facility } \\
\hline \multicolumn{6}{|l|}{ No (Ref) } \\
\hline Yes & 2.640 & 0.001 & 14.009 & 3.078 & 63.747 \\
\hline
\end{tabular}




\section{Financial Support and Sponsorship}

Nil

\section{Conflicts of interests}

The authors declare that they have no conflicts of interest.

\section{Author Contributions}

Ipinnimo TM conceptualized and designs the research. Literature search and data collection was carried out by Ipinnimo TM, Sanni TA and Ariyo OE. Statistical analysis was done by Ipinnimo TM. The manuscript was drafted by Ipinnimo TM, Sanni TA, Ariyo $\mathrm{OE}$ and Ipinnimo OM. Editing and critical review was by Ipinnimo TM and Sanni TA. All authors read and approved the final draft.

\section{References}

[1]. T Wu F, Zhao S, Yu B, Chen Y, Wang W, Song $\mathrm{Z}$ et al., 2020, A new coronavirus associated with human respiratory disease in China. Nature, 579, 265-269. doi.org/10.1038/s41586-020-2008-3.

[2]. Anjorin AA., 2020, The coronavirus disease 2019 (COVID-19 ) pandemic: A review and an update on cases in Africa. Asian Pacific Journal of Tropical Medicine, 13(5), 199-203. doi: 10.4103/1995-7645.281612.

[3]. NCDC, First-case-of-corona-virus-diseaseconfirmed-in-Nigeria, Date of access: 17/4/2020. https://ncdc.gov.ng/news/227/first-case-of-coronavirus-disease-confirmed-in-nigeria.

[4]. WHO, Coronavirus disease 2019 (COVID-19): situation report - 11. Geneva: World Health Organization, Date of access: 17/4/2020. https://www.who.int/docs/default-

source/coronaviruse/situation-reports/20200131sitrep-11-covid-19-mp.pdf.

[5]. WHO, Coronavirus disease 2019 (COVID-19): situation report - 51. Geneva: World Health Organization, Date of access: 17/4/2020. https://www.who.int/docs/default-

source/coronaviruse/situation -reports/20200311sitrep-51-covid-19.pdf.

[6]. NCDC, THE COVID-19 SITUATION REPORT SITUATION REPORT- 48. Abuja: NCDC, Date of access: 17/4/2020.

https://ncdc.gov.ng/themes/common/files/sitreps/c9b 4fa96a72b794d51d1defa03721209.pdf.

[7]. WHO, Coronavirus disease (COVID-19) pandemic. Geneva: World Health Organization, Date of access: 17/4/2020. https://www.who.int/emergencies/diseases/novelcoronavirus-2019.

[8]. ICN, ICN COVID-2019 Update: Data on infected healthcare workers and access to protective equipment vital in prevention of the virus. Geneva, Date of access: 17/4/2020.

https://www.icn.ch/news/icn-covid-2019-updatedata-infected-healthcare-workers-and-accessprotective-equipment-vital.

[9]. Elsevier, 2020, COVID-19: protecting healthcare workers. The Lancet, 395:922.

[10]. ICN, High proportion of healthcare workers with COVID-19 in Italy is a stark warning to the world : protecting nurses and their colleagues must be the number one priority. Geneva, Date of access: 17/4/2020. https://www.icn.ch/news/high-proportionhealthcare-workers-covid-19-italy-stark-warningworld-protecting-nurses-and.

[11]. Zhang WR, Wang K, Yin L, Zhao WF, Xue Q, Peng M et al., 2020, Mental Health and Psychosocial Problems of Medical Health Workers during the COVID-19 Epidemic in China. Psychotherapy Psychosomatics, 100053(45). DOI: 10.1159/000507639.

[12] Iliyasu G, Dayyab FM, Habib ZG, Tiamiyu AB, Abubakar S, Mijinyawa MS, et al., 2016, Knowledge and practices of infection control among healthcare workers in a Tertiary Referral Center in North-Western Nigeria. Annals of African Medicine, 15(1), 34-40. DOI: 10.4103/1596-3519.161724.

[13]. Lien LT, Chuc NT, Hoa NQ, Lan PT, Thoa NT, Riggi E et al., 2018, Knowledge and self-reported practices of infection control among various occupational groups in a rural and an urban hospital in Vietnam. Scientific Reports, 8,5119. DOI: 10.1038/s41598-018-23462-8.

[14]. Desta M, Ayenew T, Sitotaw N, Tegegne N, Dires M, Getie M., 2018, Knowledge , practice and associated factors of infection prevention among healthcare workers in Debre Markos referral hospital, Northwest Ethiopia. BMC Health Services Research, 18(1), 465. doi: 10.1186/s12913-018-3277-5.

[15]. Gulilat K, Tiruneh G., 2014, Assessent of knowledge, attitude and practice of health care workers on infection prevention in health institution Bahir Dar city administration. Science Journal of Public Heathl, 2(5), 384-393. doi: 10.11648/j.sjph.20140205.13.

[16]. Osuola EO, Oluwatosin A., 2017, Infection control by nurses in selected hospitals in Anambra State, Nigeria. Tropical Journal of Medical Research, 20(1), 53-60.

[17]. Shrestha GN, Thapa B., 2018, Knowledge and 
practice of infection prevention among nurses of Bir Hospiatl, Kathmandu. Journal of Nepal Health Res Counc, 16(40), 330-335.

[18]. National Population Commisision, Nigeria
2018 Demographic and Health Survey; Key Findings. Date of access: 17/4/2020.

https://dhsprogram.com. 